\title{
THE ROLE OF GOVERNMENTAL VENTURE CAPITAL IN THE VENTURE CAPITAL ECOSYSTEM: AN ORGANIZATIONAL ECOLOGY PERSPECTIVE
}

Fabio Bertoni, emlyon business school

Massimo G. Colombo, Politecnico di Milano

Anita Quas*, emlyon business school

\begin{abstract}
We use the theory of organizational ecology to study how governmental venture capital (GVC) affects the investment behavior of private venture capital (PVC). Because of its objectives and dominant competencies, GVC is a unique organizational species that occupies a different niche than and is conceived to establish mutualistic relations with PVC. Accordingly, the greater the presence of GVC in a VC ecosystem, the more PVC investors should be attracted toward GVC's niche. We consider several relevant niche dimensions at the company (age and size), industry (biotechnology) and regional (competitiveness) levels. Our analysis of 1,239 PVC investments in Europe confirms most of our predictions.
\end{abstract}

* Corresponding author: mail: quas@em-lyon.com. Phone: +33(0)4 783377 89. Address for correspondence: EMLYON business school, Department of Economics, Finance and Control, 23 Avenue Guy de Collongue, 69134 ECULLY - France. 


\section{INTRODUCTION}

Governmental venture capital (GVC) is a government-owned investment vehicle that is structured like a venture capital (VC) fund. GVC funds have been created in many countries, including the US (Lerner, 1999), Australia (Cumming \& Johan, 2009), Canada (Cumming \& Macintosh, 2006), and Europe (Bertoni, Colombo, \& Quas, 2015). They have a mandate to close the gap left by private VC (PVC) in funding innovative start-ups, to promote the creation of new jobs and to foster local development (Colombo, Cumming, \& Vismara, 2016). The aim of this paper is to assess how PVC investors' investment behavior is altered by the presence of GVC.

The literature has addressed this important issue by studying whether GVC stimulates (crowds in) or displaces (crowds out) PVC investments. Most studies investigate whether the aggregate volume of VC investments from private sources increases or decreases when GVC is introduced in a given market, obtaining mixed results (Armour \& Cumming, 2006; Brander, Du, \& Hellmann, 2015; Cumming \& Macintosh, 2006; del-Palacio, Zhang, \& Sole, 2012; Jeng \& Wells, 2000; Leleux \& Surlemont, 2003). Only a few studies use firm-level data, showing that companies that receive GVC are more likely both to receive PVC (Guerini \& Quas, 2016) and to receive a larger amount of VC funding (Brander et al., 2015).

GVC may alter the VC ecosystem not only by stimulating PVC investments but also by inducing PVC investors to target different companies (i.e., to invest in companies they would neglect in the absence of GVC). The literature has not systematically analyzed this phenomenon, with the exception of Kovner and Lerner (2015), who show that the presence of community development VC - a type of VC that has objectives similar to those of GVC - increases PVC investors' propensity to invest in underserved regions.

In this work, we use the lens of organizational ecology to investigate how GVC's density in a VC ecosystem influences the characteristics of the companies that are the target of PVC investments. Organizational ecology predicts that different organizational species in the same ecosystem may interact and that this interaction may determine changes to how those species "earn a 
living," i.e., to their niches. These theoretical lenses are particularly suitable for modeling the relationship between GVC and PVC. GVC and PVC differ markedly in terms of their objectives and dominant competencies and, therefore, can be treated as distinct organizational species (McKelvey, 1982). The theory of organizational ecology predicts that the result of the interaction between two species depends upon the extent to which their niches differ and upon the type of relationship (competitive vs. mutualistic) that the two species have. Building on Echols and Tsai (2005), we define the niches of GVC and PVC based on the specific combination of the investment opportunities pursued by the two species. Because of its political mandate, GVC invests in companies that, compared to PVC's typical targets, tend to be smaller, in earlier stages of development, in industries with longer time to market and more severe information asymmetries, and in more economically disadvantaged regions (Bertoni \& Tykvová, 2015; Kovner \& Lerner, 2015; Mason \& Harrison, 2003). Moreover, the goal of creating a GVC fund is to promote PVC development in areas of the economy in which its limited presence generates a funding gap. Accordingly, PVC and GVC have niches that overlap (as testified by the existence of syndicated investments between the two investment types) but only partially, because some investment targets that are attractive to GVC are not a natural investment target for PVC. To attract PVC investments to these companies, GVC must establish with PVC what is known in organizational ecology as a mutualistic relationship, i.e., a relationship in which the presence of one species is beneficial for the other species. We predict that if a mutualistic relationship exists between GVC and PVC, a higher density of GVC in a given VC ecosystem will make PVC investors more likely to invest in companies that are the typical target of GVC and that they would neglect in the absence of GVC.

In the empirical section of the paper, we observe VC ecosystems that differ in GVC's density and study the extent to which the PVC niche is affected by the presence of GVC. We exploit the fact that national borders represent for VC investors what geographic barriers represent for ecological populations. Institutional characteristics shape national VC markets (Bruton, Fried, \& Manigart, 2005; Jeng \& Wells, 2000), and VC investors without previous experience in cross-border deals 3 
(Meuleman \& Wright, 2011) and specific human resources (Manigart et al., 2007) are unlikely to invest internationally. We thus consider different European countries as different ecosystems. ${ }^{1}$ Europe is an interesting research setting because GVC plays a much more important role in Europe than in the US (Bertoni et al., 2015), and the extent of its presence is heterogeneous both across European countries and, for each country, over time.

Our econometric analysis takes advantage of the VICO database, which was created by the VICO research project, promoted by the European Commission's $7^{\text {th }}$ Framework Programme (Bertoni \& Martí, 2011). We use information on 1,239 first investments made between 1994 and 2004 by 676 PVC investors in 560 high-tech companies that were less than 10 years old at the time of the investment and located in seven European countries. The VICO database represents an ideal choice for our analysis because it offers an unbiased representation of the niches of PVC (and GVC), allowing us to compare seven VC ecosystems over a 10-year period.

\section{THEORY AND HYPOTHESES}

\section{The Organizational Ecology View of Governmental and Private Venture Capital}

In the organizational ecology literature, populations are collections of organizations that share the same form in a particular location and time period (Hannan \& Freeman, 1977). Manigart (1994) was the first to consider VC as a population of organizations in the sense meant by Hannan and Freeman (1977) and the first to study how the density of VC firms affects the founding rates of new VC firms. Echols and Tsai (2005) also use these theoretical lenses and focus on the product and process niches of VC investors, defined according to the type of investment opportunities that are pursued.

\footnotetext{
${ }^{1}$ The fact that in the observation period, VC markets in different European countries can be considered as distinct ecosystems, is indirectly documented by the introduction of the European venture capital passport in 2013 (European Parliament, 2013), which aimed to reduce the high barriers to cross-border intra-European VC investments (European Commission, 2007). This effort to foster cross-border VC investments is justified by the empirical evidence of a stronger positive effect of foreign VC investors on entrepreneurial ventures, for instance in terms of long term growth (Devigne, Vanacker, Manigart, \& Paeleman, 2011), ability to stop escalation commitment (Devigne, Manigart, \& Wright, 2016), and exit opportunities (Bertoni \& Groh, 2014).
} 
A population of organizations can be partitioned into different organizational species, which are subsets of the overall population characterized by different objectives and dominant competencies (McKelvey, 1982). Because of these differences, organizational species may occupy different niches (Hannan \& Freeman, 1977; McPherson, 1983). The first step of our theoretical reasoning is therefore to argue that GVC and PVC represent different organizational species and, thus, tend to occupy different niches. PVC investors' primary objective is to maximize the economic returns from their investments. Accordingly, their niche favors investments in companies that have high risk-adjusted expected return, are less exposed to information asymmetries, and enjoy advantageous environmental conditions. GVC funds have instead been created to alleviate capital market failures arising from limited supply of VC. Their aim is to provide funding for companies that are subject to more severe information asymmetries and higher investment risk (Brander et al., 2015; Colombo, Cumming, \& Vismara, 2016) and, thus, despite their potential, experience serious difficulties in obtaining the capital they need. Moreover, GVC is often motivated by broader political and social objectives, such as the creation of new jobs and the development of peripheral and economically lagging regions that lack an adequate local supply of VC (Lerner, 1999, 2002).

The dominant competencies of GVC also differ from those of PVC. Because of its political objectives and inclination to invest in riskier and informationally more opaque companies located in peripheral areas, GVC finds it difficult to attract and retain talented investment managers (Jääskeläinen, Maula, \& Murray, 2007). Hence, GVC's ability to provide portfolio companies with adequate coaching is more limited than that of PVC (Luukkonen, Deschryvere, \& Bertoni, 2013). Conversely, because of its close relationship with public bodies, GVC is ideally placed to help portfolio companies obtain additional public support (e.g., Colombo, D’Adda, \& Pirelli, 2016). ${ }^{2}$

\footnotetext{
${ }^{2} \mathrm{GVC}$ is, in turn, a collection of different types of investors that potentially constitute sub-species, including funds owned by national governments, regional authorities or public universities. PVC is also a collection of different sub-species, including independent VC, corporate VC, and bank-affiliated VC (Bertoni et al., 2015; Dimov \& Gedajlovic, 2010; Mayer, Schoors, \& Yafeh, 2005). However, we focus on aspects that all GVC and PVC investors have in common, making them two different species: the fact that PVC investments are driven by economic objectives (e.g., financial returns, technology sourcing, demand externalities), whereas GVC investments also have political objectives.
} 
The second step of our theoretical reasoning focuses on the interaction between GVC and PVC. When different species coexist in the same ecosystem, their mutual interaction will result in a shift in their niches (Hannan \& Freeman, 1977; McPherson, 1983). There are two types of interactions between species: mutualistic and competitive. In a mutualistic relationship, two species benefit from each other's presence, and their niches tend to converge, maximizing interaction (Hannan \& Carroll, 1992). In a competitive relationship, the opposite happens: two species compete for the same resources and their niches tend to diverge, minimizing interaction (McPherson \& Ranger-Moore, 1991). The organizational ecology theory suggests that the intensity of mutualistic or competitive interaction between species depends on those species' density in the ecosystem, i.e., "the number of organizations it contains" (Hannan \& Carroll, 1992, page 5; see also Carroll \& Hannan, 2000; Dobrev, Kim, \& Hannan, 2001 and Manigart, 1994, who applied this concept in the context of VC). The higher the density of a species in an ecosystem, the more other species will shift toward (mutualism) or away from (competition) its niche.

We have mentioned that GVC has the political mandate of filling the funding gap left by PVC, nurturing entrepreneurship and contributing to economic growth. To accomplish this mandate, GVC not only must insist on a niche that represents investments neglected by PVC but also must attract PVC to those investments. Therefore, GVC must create a mutualistic relationship with PVC, generating a crowding-in effect. Several factors underpin the mutualistic nature of the relationship between PVC and GVC. The first factor is risk-sharing in syndication. PVC investors may syndicate with GVC to enter new segments of the market while keeping the investment risk low (Jääskeläinen, 2012). The denser the GVC in an ecosystem, the more PVC can reap the benefits of syndication and, therefore, shift its niche toward GVCs. Second, organization ecology suggests that higher density leads to the greater legitimacy of an organizational species (Carroll \& Hannan, 1989), implying that its actions are perceived as socially acceptable, appropriate and even desirable (e.g., Suchman, 1995). Hence, an increase in GVC's density in a VC ecosystem likely leads to a greater propensity by PVC to invest like a GVC (i.e., moving toward its niche) because the latter is perceived as more legitimate. 
Third, and relatedly, the increased legitimacy that is associated with the increased density of GVC in a VC ecosystem will also intensify the strength of the signal GVC conveys when investing in a particular market niche. These signals decrease information asymmetries and, therefore, reduce screening costs for PVC (Guerini \& Quas, 2016; Martí \& Quas, 2017), attracting it to GVC's niche.

One important element of our identification strategy is that GVC's density will only affect PVC in the same VC ecosystem. Therefore, if we observe VC ecosystems with different GVC's densities, we can compare the niche of PVC across them. To this end, we will assume that countries represent distinct ecosystems for VC. This approach is particularly relevant in Europe during our observation period (1994-2004). In this period, the European VC market was fragmented because differences in administrative, regulatory and national tax policies created serious difficulties in crosscountry fundraising and investments (European Commission, 2007). Additionally, GVC investors predominantly invest domestically (Bertoni et al., 2015); therefore, it is unlikely that they can influence the behavior of PVC investors abroad. To assess the influence of GVC on PVC investors' investment behavior in the same VC ecosystem, we therefore exploit variations in the extent of the presence of GVC across European countries and over time.

\section{How GVC affects the niche of PVC}

To empirically test the extent to which GVC's density affects the PVC niche, we must identify some key dimensions along which the investments of the two organizational species are likely to differ. To do so, we build upon the extant literature (Dimov \& Gedajlovic, 2010; Mayer et al., 2005) and identify four main dimensions that characterize investee companies: age, size, industry and region.

Information asymmetries make access to external financing very problematic for young and small high-tech companies (Hall \& Lerner, 2010). These companies combine the need for substantial financial resources to fund investments with difficult access to debt capital because of their short track record and lack of collateral (Berger \& Udell, 1990). Young and small high-tech companies therefore must rely on equity financing (Carpenter \& Petersen, 2002) and would greatly benefit from 
obtaining VC. However, they often experience a severe funding gap because the information opaqueness of their innovation-based activities, the difficulties of rapidly scaling up their operations, and the associated investment risks deter PVC investments. Filling this funding gap is the objective of numerous governmental programs (Lerner, 2002). GVC's politically related objectives and dominant competencies make small, young high-tech companies a natural target of their investments. Hence, GVC is more focused than PVC on this type of company (Bertoni et al., 2015). If GVC is successful in creating a mutualistic relationship with PVC, the more GVC is present in a country in a given year, the more the niche of PVC should shift toward high-tech companies that are small and young. Hypotheses $\mathrm{H} 1$ and $\mathrm{H} 2$ follow.

\section{Hypothesis 1: PVC's tendency to invest in young high-tech companies will increase with} GVC's density in the country.

Hypothesis 2: PVC's tendency to invest in small high-tech companies will increase with GVC's density in the country.

Biotechnology plays a particularly important role for GVC. Innovation in biotechnology requires large financial investments and a very long time to break even (DiMasi \& Grabowski, 2007). Moreover, tacit, specialized knowledge embedded in the human capital of scientists is critical for the success of these science-based companies(Junkunc, 2007)(Junkunc, 2007)(Junkunc, 2007)(Junkunc, 2007)(Junkunc, 2007)(Junkunc, 2007)(Junkunc, 2007)(Junkunc, 2007)(Junkunc, 2007), exacerbating issues of asymmetric information and moral hazard and making it difficult to obtain financing from private sources (Junkunc \& Eckhardt, 2009). Because of this substantial funding gap, the role of government support is extremely important in determining the success of a country's biotechnology sector, which explains why this sector ranks high on policymakers' agenda (Giesecke, 2000; Kang \& Park, 2012). Moreover, biotech companies require significant non-financial (human, alliance) capital that is difficult to find and key to winning innovation races (Walker, Kogut, \& Shan, 1997). It is especially important to attract PVC in this sector because of its ability to provide these key resources 
and build winners (Baum \& Silverman, 2004). Accordingly, if GVC creates mutualistic relationships with PVC, we expect that a larger presence of GVC in a country shifts PVC's niche toward biotech companies, leading to hypothesis H3.

Hypothesis 3: PVC's tendency to invest in biotech companies will increase with GVC's density in the country.

GVC often has the explicit objective of fostering the economic development of less-favored regions. GVC is also ideally placed to help companies located in these regions access other policy schemes aimed at regional development (such as the structural funds of the European Union). This clearly differentiates GVC's niche from PVC's niche. Indeed, PVC is highly clustered in a few geographical areas that are generally the most economically and financially advanced (Chen, Gompers, Kovner, \& Lerner, 2010; Powell, Koput, Bowie, \& Smith-Doerr, 2002). Spatial clustering is strengthened by PVC investors' tendency to invest locally, exploiting syndication networks and circumscribed information flows (Cumming \& Dai, 2010). Driven by the evidence linking the presence of PVC to local economic growth (Samila \& Sorenson, 2011), GVC has been used - sometimes attracting criticism (Mason \& Harrison, 2003) - as a means of fostering PVC development in regions that are underserved by PVC. Accordingly, we expect that the greater the presence of GVC within a given country, the more the establishment of mutualistic relationships between PVC and GVC will drive PVC's niche toward less-favored regions. Hypothesis H4 follows.

Hypothesis 4: PVC's tendency to invest in less-developed regions will increase with GVC's density in the country.

\section{METHODS}

\section{Research Setting}

To test our hypotheses, we use the database created by the VICO research project, supported by the $7^{\text {th }}$ Framework Programme and promoted by the European Commission (Bertoni \& Martí, 2011). The database collects information on VC investments in 759 European high-tech companies over the 9 
period 1994-2004. These companies were owner-managed when founded, are located in 7 European countries (Belgium, Finland, France, Germany, Italy, Spain and the United Kingdom), operate in high-tech sectors ${ }^{3}$ and received their first VC round by their $10^{\text {th }}$ year of existence.

VICO data on VC investments were collected via random extraction from commercial databases (i.e., Thomson One, VC-PRO, and Zephyr) and country-specific proprietary databases. The data were cross-checked with those available from public sources by a central data processing unit. Through accurate data cleaning, VICO overcomes commercial databases' well-known deficiencies in the coverage of $\mathrm{VC}$ outside the US, including the overrepresentation of independent $\mathrm{VC}$ investments and the mischaracterization of GVC investments (Bertoni et al., 2015; Da Gbadji, Gailly, \& Schwienbacher, 2015). Therefore, we are confident that VICO offers an unbiased representation of the niches of PVC (and GVC) and is especially suitable for our analysis. ${ }^{4}$

The VICO database provides complete information on 1,239 first investments made by 676 PVC investors in 560 companies, which we use as our unit of analysis. Table 1 shows the distribution of the sample of PVC investments by sector and location of the company and investment year.

[Table 1 around here]

\author{
Variables and Model
}

3 VICO considers the following sectors: nanotechnology, biotechnology, pharmaceuticals, computers, electronic components, telecommunication equipment, precision, optical and medical instruments, robotics, aerospace, software, telecommunications services, internet and multimedia services, web publishing, renewable energies, R\&D and engineering services. For further details on the VICO database, see Bertoni and Martì Pellon (2011).

${ }^{4}$ To verify this claim, we formally tested the randomness of the VICO database for a selection of VC investors. For each of the four investor types included in VICO - independent, corporate, bank and governmental VC, we selected the investor with the highest number of investee companies according to VICO. The selected investors are $3 \mathrm{i}$ (independent VC in UK), Innovacom (corporate VC in France), Fortis (bank-affiliated VC in Belgium) and BPI (formerly CDC, GVC in France), which together are responsible for 117 first investments in our sample. For those investors, we collected as much information as possible on their investment history using Thomson One, Zephyr, Crunchbase and other Internet sources. Overall, we found 497 first investments by those investors between 1994 and 2004 in companies younger than 10 years at their first VC round, operating in high-tech sectors and located in the 7 countries covered by VICO. We believe this list comes very close to the population of investments made by the selected investors. For each investor, we compared the distribution of the investments in this population with that of the investments included in VICO along the following dimensions: company age at the time of the investment, sector of operation, and region of localization. We do not find any significant differences (the results of this analysis are available from the authors upon request). 
Our analysis includes four dependent variables that correspond to the four niche dimensions under consideration. The first dimension is the maturity of companies, measured by their age at the time of the investment. We generate a dummy variable Young that is equal to 1 if the investment is in a company less than 3 years old. The second niche dimension, company size, is captured by the dummy variable Micro, which - consistent with European Commission (2015) - is equal to 1 for target companies with fewer than 10 employees at the time of the investment. The third niche dimension is captured by the dummy variable Biotech, which identifies companies operating in biotechnology (Nace Rev 2. Codes 721X). The fourth niche dimension is the competitiveness of the region in which the investee company is located. This variable is measured using the Regional Competitiveness Index (RCI), an index computed at the regional (i.e., NUTS2) level by the European Commission (Annoni \& Dijkstra, 2013) and based on several indicators that reflect the development, efficiency and innovation of European regions measured between 2006 and 2011. We dichotomize the index and generate the variable $\operatorname{LowRCI}$, which is equal to 1 for investments in regions with RCI lower than the median for the group of regions included in our sample (results are similar when taking the mean value as threshold). Because all our dependent variables are dummy variables, we resort to Probit specifications and we cluster standard errors on VC investors (results are unchanged without clustering of standard errors).

Our key independent variable is GVC's density in each country and year in our sample. To measure it, we retrieved from Thomson One all the first investments made by VC investors in hightech companies. ${ }^{5}$ We then identified GVC investors. To correct for Thomson One's tendency to misclassify GVC investors, we extracted from Capital IQ the list of European VC investors whose parent company is owned by government entities and double-checked their governmental nature

\footnotetext{
${ }^{5}$ High-tech companies include all those companies that belong to the following sectors of the VEIC classification used by Thomson Reuters: Information Technology, Biotechnology, and Pharmaceuticals. Results are similar if we also include companies in Medical Diagnostics, Medical Therapeutics and Medical/Health Products of the VEIC classification. The data were downloaded in December 2016. 
using information available on their websites. We used this information to complement the list of investors classified as "Government Affiliated Programs," "Development Programs" or "University Programs" in Thomson One (results are similar if we use the original classification by Thomson One). We computed, in each country and each year, the percentage of GVC investors $(\% G V C)$ as the number of active GVC investors located in the focal country divided by the number of all active VC investors in the same country and lagged by one year. The coefficient of the variable is captured in the extent to which PVC's tendency to invest in categories of companies (i.e., young, small, biotech and located in less-developed regions, respectively) is affected by GVC's density in the country.

Some additional variables are included in the analysis to control for the fact that the positioning of a PVC investment along each niche dimension may be influenced by investment-, investor- or country-specific characteristics. The dummy variable FirstRound indicates whether the investment was the first VC investment ever received by the company, whereas the dummy variable Syndicated indicates the investments that are syndicated. Centrality is defined at the investor-year level and captures the extent to which the focal PVC investor is connected to other well-connected VC investors. We follow Hallen et al.'s (2014) approach to measuring the eigenvector centrality of the focal investor in the Thomson One database. We control for the development of national VC markets using the variable $V C o n G D P$, which gives the amount of early-stage VC investments as a percentage of GDP in each country and year (source: EVCA). Country and time dummy variables are also included in the analysis. Industry dummies are included in all models except the one in which Biotech is the dependent variable.

Table 2 illustrates the descriptive statistics and the correlation matrix for the variables used in the econometric analysis. With respect to the niche dimensions, 52.9\% of our sample PVC investments are in young companies, 33.4\% are in small companies, $20.2 \%$ are in biotech companies and $23.5 \%$ are in companies located in regions with low competitiveness.

[Table 2 around here] 


\section{RESULTS}

\section{Main results}

Table 3 presents our main econometric results. The sign and the significance of the control variables are overall in line with our expectations. FirstRound is positively associated with Young and Micro, which means that first-round VC investments tend to be in younger and smaller companies compared to follow-on investments. Syndication is less common in Micro investments and more frequent in Biotech, consistent with the fact that syndication is used more when the capital invested is larger. VConGDP and Centrality are negatively associated with Micro, suggesting that more central VC investors and investors in more-developed VC markets are less likely to invest in smaller companies.

As to our main independent variable, the coefficients of $\% G V C$ are positive and significant in models for Young (p-value $<0.01$ ), Micro (p-value $<0.001$ ) and LowRCI (p-value $<0.01$ ). The same holds true for the marginal effects (equal to 0.403 for Young, 0.432 for Micro and 0.318 for LowRCI, all with p-value $<0.01$ or better). When GVC is better represented in a country, PVC investors are more inclined to invest in younger companies, smaller companies, and companies located in lesscompetitive regions. The magnitude of the effects of GVC's density in the focal country on the probability that PVC invests in younger, smaller companies located in less-competitive regions is also sizable. If we consider an "average" investment in our sample (i.e., all continuous control variables at their mean value and all categorical variables at their mode), when GVC investors are $6.3 \%$ of the total number of VC investors $\left(15^{\text {th }}\right.$ percentile of the distribution of the $\% G V C$ variable $)$, the PVC's estimated probability of investing in young companies is $42.2 \%$, its estimated probability of investing in micro companies is $17.5 \%$ and its estimated probability of investing in lesscompetitive regions is $12.3 \%$. When GVC investors instead represent $23.8 \%$ of the VC population (corresponding to the $85^{\text {th }}$ percentile of the $\% G V C$ variable), these probabilities rise to $50.5 \%, 25.3 \%$ and $19.1 \%$ (i.e., an increase equal to 8.3 percentage points for young companies, 7.7 percentage points for micro companies and 6.7 percentage points for companies located in less-competitive regions). 
These results confirm hypotheses $\mathrm{H} 1, \mathrm{H} 2$ and $\mathrm{H} 4$. In contrast, we do not find support for hypothesis H3: \%GVC does not exert any significant impact on PVC's tendency to invest in Biotech.

[Table 3 around here]

\section{Robustness tests}

Our results are robust to a series of modifications in the econometric models. First, we measure GVC's density using the number of investments (instead of the number of investors) in each country and year (source: Thomson One database). Second, two of our dependent variables are significantly correlated: Young and Micro have a correlation of 0.29. Therefore, we use a bi-probit specification. Third, we change the measures that we use for some of our dimensions. For firm maturity, we substitute the variable Young with the variable Seed, which is 1 for investments in the seed stage. For regional development, we substitute LowRCI with the variable OutsideVCHubs, which is equal to 1 for investments that are located outside of VC hubs, defined as the top 10 regions (NUTS2) in Europe per number of VC investments in the sample period (source: Thomson One, regions identified using reported addresses of VC investors). Fourth, we repeat our analysis dropping from our sample all investments by corporate and bank-affiliated VC and considering only independent VC investors as PVC species. The results obtained after each of the abovementioned modifications in the model are qualitatively similar to those illustrated in the previous section and are available from the authors upon request.

\section{Additional results}

The European VC industry has changed during the period of our study, potentially affecting the relationships among VC types. Therefore, we study whether the association between GVC's density and PVC investors' investment behavior is different before and after the Internet bubble of 2000, which is the most important event for the VC industry during our observation period. We repeat the analysis by interacting the variable $\% G V C$ with two terms, one for each sub-period: pre-bubble and post-bubble. In Table 4, we show the results of this analysis. A Wald test (reported in the last row of 
the table) does not reject the null hypothesis that the coefficients of Pre-bubble $x \% G V C$ and Postbubble $x \% G V C$ are equal at conventional significance levels along the Young, Micro and LowRCI dimension. This result suggests that the relationship between the presence of GVC and the behavior of PVC investors that was illustrated above was at work in both sub-periods analyzed. In addition, in the pre-bubble period, GVC's density is positively and significantly (p-value<0.05) related to the likelihood that PVC investors select biotech companies as investment targets, as predicted by hypothesis H3. This relation vanishes in the post-bubble period. One possible explanation is that the maturing of the biotech industry over time may have rendered the funding gap of which biotech companies suffer less severe in the most recent period (on this aspect, see, e.g., Higgins, Stephan, \& Thursby, 2011).

[Table 4 around here]

Next, we shed some light on the mechanisms through which GVC's density influences the characteristics of PVC investment, considering the role of syndication between GVC and PVC investors. We split our sample in two sub-groups: investments in which the PVC investor syndicated with a GVC investor (i.e., a GVC investor and a PVC investor invested in the same company in the same year) and investments in which no GVC was involved. We repeat the analysis for the two subsamples. In the sub-sample of PVC investments in which GVC was not involved, we substitute Syndicated with the variable SyndicatedWithPVC, which is equal to 1 if the investment is a syndicate with other PVC investors. Results are shown in Table 5. Panel A indicates that when GVC investors are involved in the investment, GVC's density has a positive impact on PVC's tendency to invest in younger and smaller companies ( $\mathrm{p}$-value $<0.001$ and 0.01 , respectively). Panel B shows that along the Micro and LowRCI dimensions, the effect of $\% G V C$ is also significant in deals in which GVC investors were not directly involved (p-value $<0.05$ and 0.01 , respectively).

[Table 5 around here]

Thus far, we have documented that the presence of GVC in a given country influences the investments behavior of PVC investors. It is interesting to show that, instead, the niche of GVC 15 
investors is not affected by their own density. For this purpose, we repeat the analysis on a sample of 284 GVC investments extracted from the VICO database. Table 6 shows the results of this analysis. The variable $\% G V C$ is never significant, with only the partial exception of the Micro niche dimension, where it has a positive and weakly significant coefficient ( $\mathrm{p}$-value $<0.1$ ). We conclude that unlike PVC investments, GVC investment characteristics are not related to GVC's density.

[Table 6 around here]

\section{DISCUSSION AND CONCLUSION}

In this work, we have used the theoretical lenses of organizational ecology to examine how GVC's density influences PVC investors' investment behavior in a VC ecosystem. We have argued that GVC is a different species from PVC because of GVC's political objectives and distinct dominant competencies. Hence, GVC occupies a different niche from PVC. Moreover, it is inherent in the political mandate of GVC to establish mutualistic relationships with PVC, attracting PVC investors to companies they would otherwise neglect because of informational opaqueness, excessive investment risk and peripheral location. The strength of this attraction depends on GVC's density in the ecosystem. To test our predictions, we considered a random sample of VC investments in 7 European countries over the period 1994-2004. Our econometric results showed that in countries and years in which GVC was more strongly represented, PVC investors were more likely to invest in younger, smaller companies located in less-competitive regions. Because these companies are the typical target of GVC investors and are unattractive to PVC investors, we argue that these results confirm that GVC and PVC behave as organizational species in a mutualistic relationship. We also showed that syndication is one mechanism that GVC uses to attract PVC in its niche, but not the only one: even PVC investors that do not syndicate with GVC are more likely to invest in less-competitive regions and smaller companies when GVC's density is greater.

This paper offers two main contributions to the VC literature. First, several recent studies have examined the impact of the GVC programs that have been set up by governments of several countries 
with the aim of closing the funding gap left by PVC. These studies have shown that in the effects of GVC financing on portfolio companies have been limited (Colombo, Cumming, \& Vismara, 2016). Scholars have also questioned whether GVC crowds out PVC instead of attracting it to companies that need equity financing. The evidence at an aggregate level of analysis is mixed. The findings in Armour and Cumming (2006) and Cumming and Macintosh (2006) are consistent with a crowdingout effect in North America and Europe. Conversely, Jeng and Wells (2000), Leleux and Surlemont (2003), del-Palacio et al. (2012) and Brander et al. (2015) show that GVC positively affects the development of the VC industry. Studies using firm-level data also offer a positive view. Brander et al. (Brander et al., 2015) show that if GVC and PVC are both present in a company, the company receives a larger amount of VC investment than with GVC or PVC only. Guerini and Quas (2016) find that receiving GVC makes a firm three times more likely to receive PVC. Our study extends this latter stream of literature by investigating the changes triggered by the presence of GVC in a focal country in PVC investors' investment behavior located in the same country (on this topic, see also Kovner and Lerner, 2015). Our findings show that in countries in which the presence of GVC is stronger, PVC investors are more inclined to invest in firms that they tend to neglect in the absence of GVC (young, small, located in less-competitive regions).

Second, our study contributes to a small stream of studies that have applied the theoretical lens of the organizational ecology perspective to analyze VC, notably Manigart (1994) and Echols and Tsai (2005). In this study, we combine their theoretical perspectives. We discuss the niches of GVC and PVC, defined by the different characteristics of the companies in which these two VC species tend to invest, and consider how GVC's density influences PVC investors' behavior, as reflected in their niche.

This work has some limitations that open interesting avenues for future research. First, for the sake of brevity, we consider PVC a unique species. This species is quite heterogeneous, as it includes investors with different ownership and governance (Dimov \& Gedajlovic, 2010), investment experience and network embeddedness. Scholars may wish to investigate whether differences among 17 
PVC investors influence the strength of the mutualistic relationships they establish with GVC, or even give rise to competitive relationships. Similarly, not all GVC investors are alike (Jääskeläinen et al., 2007), and the design of GVC programs may influence the relationships between GVC and PVC. Second, we document empirically the existence of mutualistic relationships between GVC and PVC and show that they are not exclusively driven by syndication between the two investor types. If more detailed information were available, researchers could more closely examine the mechanisms that drive changes in PVC investment behavior, such as the certification effects of GVC investments or incentives to invest in particular companies or regions. Third, our work is based on 7 European countries. Extensions of this analysis to a larger number of countries, possibly including countries outside of Europe, would enable an examination of how institutional characteristics (e.g., investor protection, development of the stock market and the market for corporate control) moderate the intensity of the observed changes in PVC investments associated with GVC's density. Finally, data limitations force us to focus on four niche dimensions in this study. If additional information were available on the target companies selected by PVC investors, for instance, concerning the radicalness of the technology they were developing or their access to alternative financing channels such as business angels, crowdfunding or public subsidies, our analysis of the interaction between GVC and PVC could be made more comprehensive. Furthermore, future research may adopt a more detailed characterization of the niches' dimensions. For instance, while we consider companies operating in biotechnology as a single niche, it has been shown that biotechnology is a very heterogeneous sector, characterized by several fields, which could be considered as distinct sub-niches (Knockaert, Manigart, Cattoir, \& Verstraete, 2015). The non-significance of our results along the biotech niche dimension could be driven by this limitation.

Despite these limitations, our study has interesting policy implications. Our results highlight a positive effect of GVC that has previously been overlooked. Taking into consideration the widely documented positive effects of PVC on portfolio companies (Da Rin, Hellmann, \& Puri, 2013), the fact that the presence of GVC makes PVC more inclined to invest in companies it would otherwise 18 
neglect is good news for policymakers, and may offset the limited direct effects of GVC on portfolio companies. Accordingly, it would probably be wise to redefine the additionality of GVC programs in terms of their ability to redirect the "smart money" provided by PVC investors to companies that are most negatively affected by capital market imperfections.

\section{REFERENCES}

Annoni, P., \& Dijkstra, L. (2013). EU Regional Competitiveness Index - RCI 2013. https://doi.org/10.2788/61698

Armour, J., \& Cumming, D. J. (2006). The legislative road to Silicon Valley. Oxford Economic Papers, 58(4), 596-635. https://doi.org/10.1093/oep/gpl007

Baum, J. A. C., \& Silverman, B. S. (2004). Picking winners or building them? Alliance, intellectual, and human capital as selection criteria in venture financing and performance of biotechnology startups. Journal of Business Venturing, 19(3), 411-436. https://doi.org/10.1016/S08839026(03)00038-7

Berger, A. N., \& Udell, G. F. (1990). Collateral, loan quality and bank risk. Journal of Monetary Economics, 25(1), 21-42. https://doi.org/10.1016/0304-3932(90)90042-3

Bertoni, F., Colombo, M. G., \& Quas, A. (2015). The patterns of venture capital investment in Europe. Small Business Economics, 45(3), 543-560. https://doi.org/10.1007/s11187-015-9662-0

Bertoni, F., \& Groh, A. P. (2014). Cross-Border Investments and Venture Capital Exits in Europe. Corporate Governance: An International Review, 22(2), 84-99. https://doi.org/10.1111/corg.12056

Bertoni, F., \& Martí, J. (2011). Financing Entrepreneurial Ventures in Europe: The Vico Dataset (SSRN eLibrary No.1939855). SSRN eLibrary. https://doi.org/10.2139/ssrn.1904297

Bertoni, F., \& Tykvová, T. (2015). Does Governmental Venture Capital Spur Invention and Innovation? Evidence from Young European Biotech Companies. Research Policy, 44(4), 925935. https://doi.org/10.1016/j.respol.2015.02.002

Brander, J. A., Du, Q., \& Hellmann, T. F. (2015). The Effects of Government-Sponsored Venture Capital: International Evidence. Review of Finance, 19(2), 571-618. https://doi.org/10.1093/rof/rfu009

Bruton, G. D., Fried, V. H., \& Manigart, S. (2005). Institutional Influences on the Worldwide Expansion of Venture Capital. Entrepreneurship Theory and Practice, 29(6), 737-760. https://doi.org/10.1111/j.1540-6520.2005.00106.x

Carpenter, R. E., \& Petersen, B. C. (2002). Capital Market Imperfections, High-Tech Investment, and New Equity Financing. Economic Journal, 112(477), F54-F72. https://doi.org/10.1111/14680297.00683

Carroll, G. R., \& Hannan, M. T. (1989). Density Delay in the Evolution of Organizational Populations: A Model and Five Empirical Tests. Administrative Science Quarterly, 34(3), 411. https://doi.org/10.2307/2393151

Carroll, G. R., \& Hannan, M. T. (2000). The Demography of Corporations and Industries. Princeton University Press.

Chen, H., Gompers, P. A., Kovner, A., \& Lerner, J. (2010). Buy local? The geography of venture capital. Journal of Urban Economics, 67(1), 90-102. https://doi.org/10.1016/j.jue.2009.09.013

Colombo, M. G., Cumming, D. J., \& Vismara, S. (2016). Governmental Venture Capital For Innovative Young Firms. Journal of Technology Transfer, 41(1), 10-24. https://doi.org/10.1007/s10961-014-9380-9

Colombo, M. G., D’Adda, D., \& Pirelli, L. H. (2016). The participation of new technology-based 
firms in EU-funded R\&D partnerships: The role of venture capital. Research Policy, 45(2), 361375. https://doi.org/10.1016/j.respol.2015.10.011

Cumming, D. J., \& Dai, N. (2010). Local bias in venture capital investments. Journal of Empirical Finance, 17(3), 362-380. https://doi.org/10.1016/j.jempfin.2009.11.001

Cumming, D. J., \& Johan, S. (2009). Pre-seed government venture capital funds. Journal of International Entrepreneurship, 7(1), 26-56. https://doi.org/10.1007/s10843-008-0030-x

Cumming, D. J., \& Macintosh, J. G. (2006). Crowding out private equity: Canadian evidence. Journal of Business Venturing, 21(5), 569-609. https://doi.org/10.1016/j.jbusvent.2005.06.002

Da Gbadji, L., Gailly, B., \& Schwienbacher, A. (2015). International Analysis of Venture Capital Programs of Large Corporations and Financial Institutions. Entrepreneurship Theory and Practice, 39(4), 1213-1245. https://doi.org/doi: 10.1111/etap.12105

Da Rin, M., Hellmann, T. F., \& Puri, M. (2013). A Survey of Venture Capital Research. Handbook of the Economics of Finance, 2(PA), 573-648. https://doi.org/10.1016/B978-0-44-4535948.00008-2

del-Palacio, I., Zhang, X. T., \& Sole, F. (2012). The capital gap for small technology companies: public venture capital to the rescue? Small Business Economics, 38(3), 283-301. https://doi.org/10.1007/s11187-010-9275-6

Devigne, D., Manigart, S., \& Wright, M. (2016). Escalation of commitment in venture capital decision making: Differentiating between domestic and international investors. Journal of Business Venturing, 31(3), 253-271. https://doi.org/10.1016/j.jbusvent.2016.01.001

Devigne, D., Vanacker, T. R., Manigart, S., \& Paeleman, I. (2011). The role of domestic and crossborder venture capital investors in the growth of portfolio companies. Small Business Economics, 40(3), 553-573. https://doi.org/10.1007/s11187-011-9383-y

DiMasi, J. A., \& Grabowski, H. G. (2007). The cost of biopharmaceutical R\&D: is biotech different? Managerial and Decision Economics, 28(4-5), 469-479. https://doi.org/10.1002/mde.1360

Dimov, D., \& Gedajlovic, E. (2010). A Property Rights Perspective on Venture Capital Investment Decisions. Journal of Management Studies, 47(7), 1248-1271. https://doi.org/10.1111/j.14676486.2009.00905.x

Dobrev, S. D., Kim, T., \& Hannan, M. T. (2001). Dynamics of Niche Width and Resource Partitioning. American Journal of Sociology, 106(5), 1299-1337. https://doi.org/10.1086/320821

Echols, A., \& Tsai, W. (2005). Niche and performance: the moderating role of network embeddedness. Strategic Management Journal, 26(3), 219-238. https://doi.org/10.1002/smj.443

European Commission. (2007). Removing obstacles to cross-border investments by venture capital funds.

Brussels.

Retrieved

from http://ec.europa.eu/enterprise/newsroom/cf/itemdetail.cfm?item_id=2033

European Commission. (2015). User guide to the SME Defi nition. Publications Office of the European Union. Luxembourg. https://doi.org/10.2873/782201

European Parliament. (2013). Regulation (EU) No 345/2013 of the European Parliament and of the Council of 17 April 2013 on European Venture Capital Funds. Retrieved from http://eurlex.europa.eu/legal-content/EN/TXT/PDF/?uri=CELEX:32013R0345\&from=EN

Giesecke, S. (2000). The contrasting roles of government in the development of biotechnology industry in the US and Germany. Research Policy, 29(2), 205-223. https://doi.org/10.1016/S0048-7333(99)00061-X

Guerini, M., \& Quas, A. (2016). Governmental venture capital in Europe: Screening and certification. Journal of Business Venturing, 31(2), 175-195. https://doi.org/10.1016/j.jbusvent.2015.10.001

Hall, B. H., \& Lerner, J. (2010). The Financing of R\&D and Innovation. Handbook of the Economics of Innovation, 1, 609-639.

Hallen, B., Katila, R., \& Rosenberger, J. (2014). Unpacking Social Defenses: A ResourceDependence Lens on Technology Ventures, Venture Capital, and Corporate Relationships. 
Academy of Management, 57(4), 1078-1101.

Hannan, M. T., \& Carroll, G. R. (1992). Dynamics of organizational populations: Density, legitimation, and competition. Oxford University Pres.

Hannan, M. T., \& Freeman, J. H. (1977). The population ecology of organizations. American Journal of Sociology. Retrieved from http://www.jstor.org/stable/10.2307/2777807

Higgins, M. J., Stephan, P. E., \& Thursby, J. G. (2011). Conveying quality and value in emerging industries: Star scientists and the role of signals in biotechnology. Research Policy, 40(4), 605617. https://doi.org/10.1016/j.respol.2011.01.006

Jääskeläinen, M. (2012). Venture Capital Syndication: Synthesis and future directions. International Journal of Management Reviews, 14(4), 444-463. https://doi.org/10.2139/ssrn.1406989

Jääskeläinen, M., Maula, M. V. J., \& Murray, G. C. (2007). Profit distribution and compensation structures in publicly and privately funded hybrid venture capital funds. Research Policy, 36(7), 913-929. https://doi.org/10.1016/j.respol.2007.02.021

Jeng, L. A., \& Wells, P. C. (2000). The determinants of venture capital funding: evidence across countries. Journal of Corporate Finance, 6(3), 241-289. https://doi.org/10.1016/S09291199(00)00003-1

Junkunc, M. T. (2007). Managing radical innovation: The importance of specialized knowledge in the biotech revolution. Journal of Business Venturing, 22(3), 388-411. https://doi.org/10.1016/j.jbusvent.2006.04.004

Junkunc, M. T., \& Eckhardt, J. T. (2009). Technical Specialized Knowledge and Secondary Shares in Initial Public Offerings. Management Science, 55(10), 1670-1687. https://doi.org/10.1287/mnsc.1090.1051

Kang, K.-N., \& Park, H. (2012). Influence of government R\&D support and inter-firm collaborations on innovation in Korean biotechnology SMEs. Technovation, 32(1), 68-78. https://doi.org/10.1016/j.technovation.2011.08.004

Knockaert, M., Manigart, S., Cattoir, S., \& Verstraete, W. (2015). A perspective on the economic valorization of gene manipulated biotechnology: Past and future. Biotechnology Reports, 6, 5660. https://doi.org/10.1016/j.btre.2015.01.002

Kovner, A., \& Lerner, J. (2015). Doing Well by Doing Good? Community Development Venture Capital. Journal of Economics \& Management Strategy, 24(3), 643-663. https://doi.org/10.1111/jems.12100

Leleux, B., \& Surlemont, B. (2003). Public versus Private Venture Capital: Seeding or Crowding Out? A Pan-European Analysis. Journal of Business Venturing, 18(1), 81-104. https://doi.org/10.1016/S0883-9026(01)00078-7

Lerner, J. (1999). The Government as Venture Capitalist: The Long-Run Impact of the SBIR Program. Journal of Business, 72(3), 285-318. https://doi.org/10.3905/jpe.2000.319960

Lerner, J. (2002). When Bureaucrats Meet Entrepreneurs: The Design of Effective "Public Venture Capital” Programmes. Economic Journal, 112(477), F73-F84. https://doi.org/10.1111/14680297.00684

Luukkonen, T., Deschryvere, M., \& Bertoni, F. (2013). The value added by government venture capital funds compared with independent venture capital funds. Technovation, 33(4-5), 154162. https://doi.org/10.1016/j.technovation.2012.11.007

Manigart, S. (1994). The founding rate of venture capital firms in three European countries (19701990). Journal of Business Venturing, 9(6), 525-541. https://doi.org/10.1016/08839026(94)90020-5

Manigart, S., Collewaert, V., Wright, M., Pruthi, S., Lockett, A., Bruining, H., ... Landstrom, H. (2007). Human capital and the internationalisation of venture capital firms. International Entrepreneurship and Management Journal, 3(1), 109-125. https://doi.org/10.1007/s11365006-0021-0

Martí, J., \& Quas, A. (2017). A beacon in the night: government certification of SMEs towards banks. Small Business Economics, 1-17. https://doi.org/10.1007/s11187-016-9828-4 
Mason, C. M., \& Harrison, R. T. (2003). Closing the Regional Equity Gap? A Critique of the Department of Trade and Industry's Regional Venture Capital Funds Initiative. Regional Studies, 37(8), 855-868. https://doi.org/10.1080/0034340032000128767

Mayer, C., Schoors, K., \& Yafeh, Y. (2005). Sources of funds and investment activities of venture capital funds: evidence from Germany, Israel, Japan and the United Kingdom. Journal of Corporate Finance, 11(3), 586-608. https://doi.org/10.1016/j.jcorpfin.2004.02.003

McKelvey, B. (1982). Organizational systematics--taxonomy, evolution, classification. University of California Press.

McPherson, J. M. (1983). An ecology of affiliation. American Sociological Review, 48(4), 519-532. Retrieved from http://www.jstor.org/stable/2117719

McPherson, J. M., \& Ranger-Moore, J. R. (1991). Evolution on a Dancing Landscape: Organizations and Networks in Dynamic Blau Space. Social Forces, 70(1), 19-42. https://doi.org/10.1093/sf/70.1.19

Meuleman, M., \& Wright, M. (2011). Cross-border private equity syndication: Institutional context and learning. Journal of Business Venturing, 26(1), 35-48. https://doi.org/10.1016/j.jbusvent.2009.06.003

Powell, W. W., Koput, K. W., Bowie, J. I., \& Smith-Doerr, L. (2002). The Spatial Clustering of Science and Capital: Accounting for Biotech Firm-Venture Capital Relationships. Regional Studies, 36(3), 291-305. https://doi.org/10.1080/00343400220122089

Samila, S., \& Sorenson, O. (2011). Venture capital, entrepreneurship, and economic growth. The Review of Economics and Statistics, 93(1), 338-349. Retrieved from http://www.mitpressjournals.org/doi/abs/10.1162/REST_a_00066

Suchman, M. C. (1995). Managing Legitimacy: Strategic and Institutional Approaches. Academy of Management Review, 20(3), 571-610. https://doi.org/10.5465/AMR.1995.9508080331

Walker, G., Kogut, B., \& Shan, W. (1997). Social Capital, Structural Holes and the Formation of an Industry Network. Organization Science, 8(2), 109-125. https://doi.org/10.1287/orsc.8.2.109 
TABLES AND FIGURES

Table 1: Distribution of the sample PVC investments by sector of operation and location of the investee companies and investment year

\begin{tabular}{lrrlrr}
\hline \hline & No & $\%$ & & No & $\%$ \\
\hline Sector of operation of the company & & & Investment year & & \\
Internet & 192 & 15.50 & 1994 & 1 & 0.08 \\
Telecommunication services & 65 & 5.25 & 1995 & 1 & 0.08 \\
Biotech and pharmaceuticals & 306 & 24.70 & 1996 & 9 & 0.73 \\
ICT manufacturing a & 213 & 17.19 & 1997 & 31 & 2.50 \\
Software & 431 & 34.79 & 1998 & 56 & 4.52 \\
Other high-tech industries & 32 & 2.58 & 1999 & 116 & 9.36 \\
Total & 1239 & 100.00 & 2000 & 303 & 24.46 \\
& & & 2001 & 250 & 20.18 \\
Location of the company & & & 2002 & 203 & 13.33 \\
Belgium & 135 & 10.90 & 2003 & 152 & 12.27 \\
Finland & 76 & 6.13 & 2004 & 157 & 12.67 \\
France & 322 & 25.99 & Total & & 100.00 \\
Germany & 252 & 20.34 & & & \\
Italy & 43 & 3.47 & & & \\
Spain & 47 & 3.79 & & & \\
United Kingdom & 364 & 29.38 & & & \\
Total & 1239 & 100.00 & & & \\
\hline \hline
\end{tabular}

${ }^{a}$ This category includes electronic components, computers, telecommunication equipment, electronic, medical and optical instruments

Table 2: Descriptive statistics and correlation matrix

\begin{tabular}{llllllllllllll}
\hline \hline Variable & N & \multicolumn{1}{c}{ Mean } & Std Dev & Min & Max & $\mathbf{1}$ & $\mathbf{2}$ & $\mathbf{3}$ & $\mathbf{4}$ & $\mathbf{5}$ & $\mathbf{6}$ & $\mathbf{7}$ & $\mathbf{8}$ \\
\hline $\mathbf{1}$ FirstRound & 1,239 & 0.665 & 0.472 & 0.000 & 1.000 & 1.00 & & & & & & & \\
$\mathbf{2}$ Syndicated & 1,239 & 0.707 & 0.455 & 0.000 & 1.000 & -0.25 & 1.00 & & & & & \\
$\mathbf{3}$ Centrality & 1,239 & 0.007 & 0.020 & 0.000 & 0.138 & -0.07 & 0.09 & 1.00 & & & & \\
$\mathbf{4}$ VConGDP & 1,239 & 0.048 & 0.031 & 0.003 & 0.105 & 0.11 & 0.14 & 0.07 & 1.00 & & & \\
$\mathbf{5}$ \%GVC & 1,239 & 0.159 & 0.121 & 0.000 & 1.000 & -0.08 & -0.12 & 0.00 & -0.26 & 1.00 & & & \\
$\mathbf{6}$ Young & 1,239 & 0.529 & 0.499 & 0.000 & 1.000 & 0.32 & -0.07 & -0.02 & 0.07 & 0.05 & 1.00 & & \\
$\mathbf{7}$ Micro & 860 & 0.334 & 0.472 & 0.000 & 1.000 & 0.32 & -0.17 & -0.13 & -0.10 & 0.15 & 0.29 & 1.00 & \\
$\mathbf{8}$ Biotech & 1,239 & 0.202 & 0.401 & 0.000 & 1.000 & 0.03 & 0.12 & -0.03 & -0.08 & 0.03 & 0.06 & 0.11 & 1.00 \\
$\mathbf{9}$ LowRCI & 1,239 & 0.235 & 0.424 & 0.000 & 1.000 & 0.07 & -0.07 & -0.07 & -0.29 & 0.19 & -0.04 & 0.12 & -0.14 \\
\hline \hline
\end{tabular}


Table 3: Results of the econometric analysis: Impact of GVC's density on the characteristics of PVC investments

\begin{tabular}{|c|c|c|c|c|c|c|c|c|}
\hline \multirow{3}{*}{$\begin{array}{l}\text { Dependent Variable } \\
\text { FirstRound }\end{array}$} & \multicolumn{2}{|l|}{ I } & \multicolumn{2}{|l|}{ II } & \multicolumn{2}{|c|}{$\begin{array}{c}\text { III } \\
\text { Biotech }\end{array}$} & \multicolumn{2}{|c|}{$\begin{array}{c}\mathrm{IV} \\
\text { LowRCI }\end{array}$} \\
\hline & 0.984 & $* * *$ & 1.019 & $* * *$ & \multicolumn{2}{|c|}{0.086} & \multicolumn{2}{|l|}{0.166} \\
\hline & $(0.089)$ & & (0.113) & & $(0.101)$ & & (0.109) & \\
\hline \multirow[t]{2}{*}{ Syndicated } & -0.060 & & -0.389 & $* *$ & 0.351 & $* *$ & -0.046 & \\
\hline & $(0.097)$ & & $(0.120)$ & & $(0.111)$ & & $(0.133)$ & \\
\hline \multirow[t]{2}{*}{ Centrality } & 0.275 & & -6.975 & $*$ & -2.095 & & -2.431 & \\
\hline & (2.267) & & (3.374) & & (2.297) & & (2.508) & \\
\hline \multirow[t]{2}{*}{ VConGDP } & 0.970 & & -7.212 & $* *$ & -2.993 & & -2.850 & \\
\hline & (1.685) & & (2.524) & & (1.834) & & $(2.048)$ & \\
\hline \multirow[t]{2}{*}{$\% G V C$} & 1.196 & $* *$ & 1.522 & $* * *$ & 0.467 & & 1.616 & $* * *$ \\
\hline & $(0.450)$ & & $(0.453)$ & & $(0.369)$ & & $(0.487)$ & \\
\hline \multirow[t]{2}{*}{ Constant } & -0.296 & & 0.262 & & -1.097 & $* * *$ & -1.609 & $* * *$ \\
\hline & $(0.207)$ & & $(0.285)$ & & $(0.217)$ & & $(0.381)$ & \\
\hline $\mathrm{N}$ & 1239 & & 860 & & 1239 & & 1239 & \\
\hline$\chi^{2}[\mathrm{DoF}]$ & 200.96 [17] & $* * *$ & 180.91 [17] & $* * *$ & 81.74 [12] & $* * *$ & $4827.58[17]$ & $* * *$ \\
\hline Pseudo $\mathrm{R}^{2}$ & 0.144 & & 0.212 & & 0.083 & & 0.353 & \\
\hline
\end{tabular}

The table shows coefficients and standard errors of four probit regressions, whose dependent variable is specified in the first row. Standard errors (in brackets) are clustered for the 676 investors. Country, time and industry (except for model III) dummies are included in the analysis but are omitted from the table. The highest average VIF is 2.64 , for model II. *p-value $<0.05$; **p-value $<0.01$; ***p-value $<0.001$.

Table 4: Additional evidence: Pre and Post Internet Bubble

\begin{tabular}{lcccc}
\hline \hline & I & II & III & IV \\
Dependent Variable & Young & Micro & Biotech & LowRCI \\
\hline FirstRound & $0.989 * * *$ & $1.021 * * *$ & 0.082 & 0.166 \\
& $(0.089)$ & $(0.114)$ & $(0.101)$ & $(0.109)$ \\
Syndicated & -0.062 & $-0.391 * *$ & $0.355 * *$ & -0.048 \\
& $(0.097)$ & $(0.120)$ & $(0.111)$ & $(0.134)$ \\
Centrality & 0.088 & $-7.066 *$ & -1.795 & -2.447 \\
& $(2.300)$ & $(3.396)$ & $(2.314)$ & $(2.510)$ \\
VConGDP & 1.102 & $-7.155 * *$ & $-3.062 \dagger$ & -2.827 \\
& $(1.689)$ & $(2.519)$ & $(1.838)$ & $(2.057)$ \\
Pre-bubble $x \% G V C(\alpha)$ & 0.676 & $1.282 *$ & $1.165 *$ & $1.493 *$ \\
& $(0.582)$ & $(0.581)$ & $(0.553)$ & $(0.629)$ \\
Post-bubble $x \% G V C(\beta)$ & $1.938 * *$ & $1.744 *$ & -0.441 & $1.788 *$ \\
& $(0.697)$ & $(0.692)$ & $(0.565)$ & $(0.828)$ \\
Constant & -0.299 & 0.275 & $-1.113 * * *$ & $-1.609 * * *$ \\
& $(0.209)$ & $(0.286)$ & $(0.224)$ & $(0.381)$ \\
\hline $\mathrm{N}$ & 1239 & 860 & 1239 & 1239 \\
$\chi^{2}[$ DoF] & $205.03[18] * * *$ & $186.27[18] * * *$ & $84.63[13] * * *$ & $5053.22[18] * * *$ \\
Pseudo R $\mathrm{R}^{2}$ & 0.145 & 0.212 & 0.086 & 0.353 \\
Test $\alpha=\beta$ & 1.775 & 0.255 & $3.780 \dagger$ & 0.077 \\
\hline \hline
\end{tabular}

The table shows coefficients and standard errors of four probit regressions, whose dependent variable is specified in the first row. Standard errors (in round brackets) are clustered for the 676 investors. Country, time and industry (except for model III) dummies, are also included in the analysis but are omitted from the table. $\dagger$ p-value $<0.1 ; *$ p-value $<0.05 ; * *$ p-value $<0.01 ; * * *$ p-value $<0.001$. 
Table 5: Additional evidence: Effect of syndication with GVC

\begin{tabular}{|c|c|c|c|c|c|c|c|c|}
\hline Dependent Variable & $\begin{array}{c}\text { I } \\
\text { Young }\end{array}$ & & \multicolumn{2}{|l|}{$\begin{array}{c}\text { II } \\
\text { Micro }\end{array}$} & \multicolumn{2}{|l|}{$\begin{array}{c}\text { III } \\
\text { Biotech } \\
\end{array}$} & \multicolumn{2}{|l|}{$\begin{array}{c}\mathrm{IV} \\
\text { LowRCI }\end{array}$} \\
\hline \multicolumn{9}{|c|}{ Panel A: Syndication with GVC } \\
\hline FirstRound & $\begin{array}{r}1.950 \\
(0.262)\end{array}$ & $* * *$ & $\begin{array}{r}1.077 \\
(0.260)\end{array}$ & $* * *$ & $\begin{array}{r}-0.396 \\
(0.195)\end{array}$ & $*$ & $\begin{array}{r}0.513 \\
(0.217)\end{array}$ & $*$ \\
\hline Centrality & $\begin{array}{r}3.944 \\
(3.896)\end{array}$ & & $\begin{array}{r}-15.158 \\
(8.992)\end{array}$ & $\dagger$ & $\begin{array}{r}-2.582 \\
(3.959)\end{array}$ & & $\begin{array}{r}-7.019 \\
(4.386)\end{array}$ & \\
\hline$V C o n G D P$ & $\begin{array}{r}9.129 \\
(4.813)\end{array}$ & $\dagger$ & $\begin{array}{r}-9.234 \\
(6.738)\end{array}$ & & $\begin{array}{r}-0.690 \\
(4.040)\end{array}$ & & $\begin{array}{r}-8.593 \\
(4.941)\end{array}$ & $\dagger$ \\
\hline$\% G V C$ & $\begin{array}{r}6.536 \\
(1.599)\end{array}$ & $* * *$ & $\begin{array}{r}5.243 \\
(1.802)\end{array}$ & $* *$ & $\begin{array}{r}1.204 \\
(0.994)\end{array}$ & & $\begin{array}{r}0.189 \\
(1.630)\end{array}$ & \\
\hline Constant & $\begin{array}{r}-2.303 \\
(0.590) \\
\end{array}$ & $* * *$ & $\begin{array}{r}-1.023 \\
(0.759) \\
\end{array}$ & & $\begin{array}{r}-0.285 \\
(0.471) \\
\end{array}$ & & $\begin{array}{r}-1.884 \\
(0.612) \\
\end{array}$ & $* *$ \\
\hline $\mathrm{N}$ & 284 & & 202 & & 284 & & 284 & \\
\hline $\begin{array}{l}\chi^{2} \\
\text { Pseudo } \mathrm{R}^{2}\end{array}$ & $\begin{array}{r}1205.30[16] \\
0.417\end{array}$ & $* * *$ & $\begin{array}{r}4441.51[16] \\
0.321 \\
\end{array}$ & $* * *$ & $\begin{array}{r}370.19[11] \\
0.098 \\
\end{array}$ & $* * *$ & $\begin{array}{r}3234.05[16] \\
0.362 \\
\end{array}$ & $* * *$ \\
\hline Panel B: No syndic: & with GVC & & & & & & & \\
\hline FirstRound & $\begin{array}{r}0.854 \\
(0.101)\end{array}$ & $* * *$ & $\begin{array}{r}1.099 \\
(0.139)\end{array}$ & $* * *$ & $\begin{array}{r}0.263 \\
(0.133)\end{array}$ & $*$ & $\begin{array}{r}0.054 \\
(0.130)\end{array}$ & \\
\hline SyndicatedWithPVC & $\begin{array}{r}0.656 \\
(2.564)\end{array}$ & & $\begin{array}{r}-4.236 \\
(3.451)\end{array}$ & & $\begin{array}{r}-1.133 \\
(2.882)\end{array}$ & & $\begin{array}{r}-1.669 \\
(3.356)\end{array}$ & \\
\hline Centrality & $\begin{array}{r}0.675 \\
(1.889)\end{array}$ & & $\begin{array}{r}-6.871 \\
(2.813)\end{array}$ & $*$ & $\begin{array}{r}-4.596 \\
(2.038)\end{array}$ & $*$ & $\begin{array}{r}-1.110 \\
(2.362)\end{array}$ & \\
\hline$V C o n G D P$ & $\begin{array}{r}-0.059 \\
(0.103)\end{array}$ & & $\begin{array}{r}-0.382 \\
(0.130)\end{array}$ & $* *$ & $\begin{array}{r}0.177 \\
(0.130)\end{array}$ & & $\begin{array}{r}-0.031 \\
(0.138)\end{array}$ & \\
\hline$\% G V C$ & $\begin{array}{r}0.633 \\
(0.457)\end{array}$ & & $\begin{array}{r}1.068 \\
(0.503)\end{array}$ & $*$ & $\begin{array}{r}-0.103 \\
(0.503)\end{array}$ & & $\begin{array}{r}1.715 \\
(0.557)\end{array}$ & $* *$ \\
\hline Constant & $\begin{array}{r}-0.250 \\
(0.242)\end{array}$ & & $\begin{array}{r}0.208 \\
(0.333) \\
\end{array}$ & & $\begin{array}{r}-1.203 \\
(0.287)\end{array}$ & $* * *$ & $\begin{array}{r}-1.380 \\
(0.460)\end{array}$ & $* *$ \\
\hline $\mathrm{N}$ & 955 & & 658 & & 955 & & 955 & \\
\hline $\begin{array}{l}\chi^{2}[\mathrm{DoF}] \\
\text { Pseudo } \mathrm{R}^{2}\end{array}$ & $\begin{array}{r}130.94[17] \\
0.116\end{array}$ & $* * *$ & $\begin{array}{r}609.51[17] \\
0.218\end{array}$ & $* * *$ & $\begin{array}{r}80.67[12] \\
0.114\end{array}$ & $* * *$ & $\begin{array}{r}3355.82[17] \\
0.379\end{array}$ & $* * *$ \\
\hline
\end{tabular}

The table shows coefficients and standard errors of two sets of four probit regressions, whose dependent variable is specified in the first row. In Panel A, only PVC investments in which also a GVC was part of the syndicate are included. In Panel B, only PVC investments in which no GVC was involved are included. Standard errors (in round brackets) are clustered for the PVC investors. Country, time and industry (except for model III) dummies, are included in the analysis but are omitted from the table. $\uparrow \mathrm{p}$-value $<0.1$; ${ }^{*} \mathrm{p}$-value $<0.05$; $* *$ p-value $<0.01 ; * * *$ p-value $<0.001$. 
Table 6: Additional evidence: Impact of GVC presence on the characteristics of GVC investments

\begin{tabular}{|c|c|c|c|c|c|c|c|c|}
\hline \multirow{3}{*}{$\begin{array}{l}\text { Dependent Variable } \\
\text { FirstRound }\end{array}$} & \multicolumn{2}{|l|}{$\begin{array}{c}\text { I } \\
\text { Young }\end{array}$} & \multicolumn{2}{|l|}{$\begin{array}{c}\text { II } \\
\text { Micro }\end{array}$} & \multicolumn{2}{|l|}{$\begin{array}{c}\text { III } \\
\text { Biotech }\end{array}$} & \multicolumn{2}{|l|}{$\begin{array}{c}\text { IV } \\
\text { LowRCI }\end{array}$} \\
\hline & 1.459 & $* * *$ & 0.373 & & -0.194 & & 0.531 & $*$ \\
\hline & $(0.271)$ & & $(0.272)$ & & $(0.200)$ & & $(0.215)$ & \\
\hline \multirow[t]{2}{*}{ Syndicated } & -0.612 & $*$ & -0.909 & $* * *$ & -0.023 & & 0.167 & \\
\hline & $(0.247)$ & & $(0.255)$ & & $(0.153)$ & & (0.197) & \\
\hline \multirow[t]{2}{*}{ Centrality } & -126.937 & & -129.530 & & 74.977 & & -257.144 & $* * *$ \\
\hline & $(78.417)$ & & $(78.843)$ & & $(66.210)$ & & (74.217) & \\
\hline \multirow[t]{2}{*}{ VConGDP } & 5.074 & & -0.402 & & 5.187 & & -6.683 & \\
\hline & (3.885) & & $(6.082)$ & & (3.737) & & (4.236) & \\
\hline \multirow[t]{2}{*}{$\% G V C$} & 0.770 & & 1.371 & $\dagger$ & 0.298 & & 0.709 & \\
\hline & $(0.786)$ & & (0.779) & & $(0.620)$ & & $(0.982)$ & \\
\hline \multirow[t]{2}{*}{ Constant } & -0.714 & & 1.231 & $\dagger$ & -0.850 & $*$ & -1.634 & $* *$ \\
\hline & $(0.558)$ & & $(0.652)$ & & $(0.366)$ & & $(0.556)$ & \\
\hline $\mathrm{N}$ & 284 & & 174 & & 284 & & 284 & \\
\hline$\chi^{2}[\mathrm{DoF}]$ & $975.46[17]$ & $* * *$ & $49.11[17]$ & $* * *$ & $465.69[12]$ & $* * *$ & 676.98 [17] & $* * *$ \\
\hline Pseudo $\mathrm{R}^{2}$ & 0.269 & & 0.201 & & 0.111 & & 0.385 & \\
\hline Log Likelihood & -131.78 & & -95.867 & & -153.343 & & -113.294 & \\
\hline
\end{tabular}

The table shows coefficients and standard errors of four probit regressions, whose dependent variable is specified in the first row. Standard errors (in round brackets) are clustered for the 110 GVC investors. Country, time and industry dummies (except for model III) are also included in the analysis but are omitted from the table. The highest average VIF is 3.89 , for model III. $\dagger \mathrm{p}$-value $<0.1$; ${ }^{*} \mathrm{p}$-value $<0.05 ; * * \mathrm{p}$-value $<0.01$; $* * *$ value $<0.001$. 